\title{
Interactivity and Branding, public political communication as a marketing tool
}

\author{
Darren G. Lilleker (Bournemouth University) \\ \& \\ Nigel Jackson (Plymouth University)
}

\begin{abstract}
Effective communication is essential for brands to gain awareness, interest and loyalty from their consumers; the same is as true for politics as for any manufacturer or service provider. The challenge for political parties and candidates seeking support or election is finding the means to transmit their messages to an increasingly hard to reach audience. The consumer within a political context may avoid hard news or broadcast political debate, discard any direct mail received and, when receiving glimpses of political communication, simple reject any political messages as spin and propaganda. In order that brand values are accepted and understood and accepted effective, unmediated communication is crucial and increasingly political communication strategists are turning to the Internet which can not only enable the reaching of a wider audience but can also complement and augment the brand character.
\end{abstract}

As new technologies are adopted, new modes of communication are also introduced. While a website can act as a shop front from which parties or candidates can advertise their policies and personnel, the style of the site (design, language and features) can act as metaphors for the professionalism and style of representation offered. To appear modern parties are increasingly adopting Web 2.0 tools, platforms and features. These all permit, to differing degrees, users to interact with parties and candidates and have conversations across online platforms. This interactivity can, if used strategically, be used as a tool for branding a party or candidate given that the uses of such tools can be metaphors for openness, accessibility and the representational character that may be provided post election. We explore this issue drawing on original empirical data gathered through analyses of online activities during the French and US presidential contests of 2007 and 2008 and of UK parties and MPs during 2008 and 2009. Through a process of creating narratives for each of the brands analysed, based upon a content and discourse analysis of the websites and other online presences, we identify what characteristics the online shop front is designed to project. These narratives, cumulatively, suggest that the online environment is becoming a key communicational tool for those who seek election, and potentially a key source of information for the voter; thus an important location to place strategic branded information. However it appears that interactivity is better suited to the activities of candidates, nationally or locally, due to the individualistic nature of conversational interactivity. Interactivity can thus have a significant role to play within a presidential contest where the individual is seeking office, but when representatives attempt to construct their individual brand it can also challenge traditional hierarchies within party based parliamentary systems such as the UK. 
Interactivity and Branding, public political communication as a marketing tool

Communicating the Political Brand

While it may not be common to view politicians or political parties as brands, there are clear similarities (Lloyd, 2005). While most commercial products tend to be tangible and so brands are judged by consumers on levels of satisfaction provided by their products; political products are less tangible and so political performance may be judged on perceived brand characteristics as opposed to specific policy outcomes. Such concepts explain the dichotomy between the Teflon and Velcro leaders, ones to which negative occurrences are deemed beyond their responsibility or which impact heavily upon their performance ratings (Newman, 1999). At the heart of the political brand is the core ethos of the party; core ideological premises and constraints often shaped by their history and synonymous with key players. Viewing the brand as having multiple layers (Aaker, 1997; Lilleker, 2006), one then sees key personnel surrounding and contributing to that core ethos; these individuals and the style in which they communicate will play a significant role in shaping current perceptions of the brand (Lilleker, 2006).

It is recognised that behaviour creates impressions and attitudes about the individual or organisation (Fill, 2005). Elements of a brand's outward behaviour from the immediate customer service in outlets to various aspects, such as ethical policies covered under the broad umbrella of corporate social responsibility, can all have a significant impact on perceptions of the brand's character and so shape impressions and attitudes (Keller, 1993; Duncan \& Moriarty, 1998; McDonald et al, 2001). Political parties and candidates for office have long relied upon the mass media to broadcast to their audience, it is their mode of advertising, and so like many major household brand names build impressions through sustained coverage (Deephouse, 2000; Hoogheimstra, 2000). Coverage can be purely political, but as we move into an age of celebrification there is more stress on the personal life and character of individuals (Street, 1997; Corner \& Pels, 2003). This places party leaders as central to building brand characters, and introduces a demotic turn to political campaigning (Turner, 2008). However, with the mass media becoming increasingly market-oriented, politics can be sidelined and heavily mediated to the extent that impressions can not be directly formed regarding parties or individuals. Getting party or candidate messages out can be increasingly difficult as they are presented within an emerging genre that Caulfield (2008) calls 'infoenterpropagainment'. Using this term to cover much mediated political communication, Caulfield argues that both politicians and media blend political information with aspects of propaganda, including media or political bias, and present it to the audience in a way that entertains. This is used to explain the culture of spin at the heart of modern political communication, but also the framing of political news within discussions of battles between personalities, internal and inter-party conflicts and the horserace elements of campaigning (Jackson, 2009). Given that media representations can often lead to the audience being left with subverted and/or negative impressions of political parties and candidates, alternative means are sought to reach potential voters (Lusoli, Ward \& Gibson, 2002). 
The Internet can offer a range of opportunities for parties and candidates to build shop fronts for online audiences to view their wares. Websites, profiles across a range of social networking sites (SNS), particularly Facebook given the global audience it now receives; file sharing sites such as YouTube (for videos) or Flickr (photographs); and microblogging sites with Twitter being the most widely used, all can provide impressions of the character of the party, party leader, key players or individual candidates. We suggest that, while many of the followers, friends and frequent visitors to these online presences may be highly involved supporters, each may offer impressions to a range of visitors who may be seeking cues to inform their voter choice. Content of specific feeds, such as Twitter, may offer certain types of impressions to visitors (Jackson \& Lilleker, 2010); however the potential to engage in a degree of interaction with the site or elements of it, with the host privately, or publicly with the host and other users equally has significant potential to create positive impressions (Sundar et al. 2003).

\section{Introducing Interactivity}

Interactivity has recently been given a new lease of life within studies of political communication. While the term has a long history, and is at the centre of a number of definitional debates, Web 2.0 technologies, and their capacity to allow conversations to take place among multiple participants online has allowed interactivity to be seen as a mainstream activity central to the concepts of Web 2.0 and the network society (O'Reilly, 2005; Van Dijk, 2009). While there are a range of debates regarding how organisations can harness the potential of this communicative environment, perhaps political parties and candidates, within their remit of serving democracy, are best placed to embed features that encourage interactivity to their communication strategy. This paper will, therefore, focus on whether the existence of Web 2.0 applications encourages greater interactivity between political actors and citizens within online political communication, and evaluate its potential for building the brand identity of parties and candidates.

Interactivity has been defined historically as any form of communication that replicates face-toface conversation: "an expression of the extent that in a given series of communication exchanges, any third (or later) transmission (or message) is related to the degree to which previous exchanges referred to even earlier transmissions" (Rafaeli 1988: 111). Building upon the work of Rafaeli, Kioussis (2002), approaching the subject from a public relations perspective, also places conversation as key to recognising interactivity. The inception of the Internet, and the ability of Internet users to shape their experiences through following links, playing videos and joining discussion forum have led to some stretching of the concept of interactivity and suggestions that any click equates to a degree of interactivity due to its experiential and perceptual nature (Bucy 2004). Stromer-Galley (2004), contextualising interactivity within a political context, presents a dichotomy between interactivity facilitated by technology and technologies that facilitate interaction between individuals. Interactivity-as-product encapsulates the broad technological applications such as click-thrus, hyperlinks, downloads or indeed web feeds such as RSS. These allow interaction with a website, but are essentially ways of allowing visitors to navigate easily and selectively between pages or indeed sites. In contrast, interactivityas-process is, as suggested, the process by which human beings converse. As online technologies have developed, such definitions have also been refined to encompass new ways in which 
conversations can take place. As Stromer-Galley encapsulates the argument "By asking what opportunities are made available by elites and whether and how citizens use those opportunities, this line of investigation focuses on interactivity-as-product. Asking what transpires when citizens interact with elites is an interactivity-as-process question" (Stromer-Galley, 2004: 393).

This redefinition draws on the work of Sally McMillan (2002). Her typology offers three levels of interactivity; the most basic is the user's ability to interact with an online item. This can be simply the choice of accessing a file, reading, listening or watching or it can involve choosing which links to follow which can offer each user a unique experience. However, while allowing a form of interaction, this is a long way from ideals of interactivity. The second level of interactivity for McMillan is an ability to interact with the system. Here the user is able to choose what to access and how to access it, for example news is delivered to the desktop via RSS feeds, and equally users can take part in file sharing activities and have access to a wide variety of information and material. McMillan positions as the highest form of interactivity the user-to-user variant. This is evidenced where file sharing can be accompanied by conversation and coproduction. Users are able to shape other user's experiences (becoming produsers: a combination of producer and user of content) of music, video as well as adding messages, comments or having public conversations. This latter style of interactivity fits well with the 'big ideas' of Web 2.0 (O'Reilly, 2005: Anderson, 2007; Chadwick, 2009) as well as ideals of communication (Grunig \& Hunt 1984).

Where McMillan's model applied to all communication channels and all communication disciplines, Ferber et al. (2007) updated this in two ways, first in suggesting that interactivity is best applied to politics via the Internet and by adding a new dimension: three-way communication. Within both models one-way communication is monologic with low receiver control, but some feedback may be allowed. Usually feedback is communicated privately via email. Two-way communication can be representations of dialogue repackaged upon a website. Instances of two-way communication under a condition of low receiver control may be frequently asked questions or a synopsis of online, privately communicated suggestions, or off line discussions. Higher receiver control is allowed where dialogue is presented, possibly verbatim, or where comments can be made under moderated conditions. Three-way communication, however, facilitates conversations that would link best to classical definitions of interactivity. They may be controlled to some extent, moderated at the very least, but the host of the site and multiple users should be allowed to engage in open conversation. This is particularly the case with three way communication under a condition of high receiver control. Here all participants have equal rights to post links, videos, items, comments and take part in what Levine et al. in The Cluetrain Manifesto (1999) referred to as a global conversation. This is argued to be the potential offered by interactive online features, features which offer spaces for the ideal of communication that has been likened to Habermas' definition of ideal speech within a public sphere (Lilleker \& Malagon, 2010). We suggest that the different types of interactivity that parties and candidates permit may play a significant contribution to the branding of parties, their leaders and candidates for office?

\section{Interactive Political Communication}

Political communication, defined for this purpose as any spoken, written or visual messages and images emitting from political organisations standing for election, fits within a non-interactive, hierarchical, top-down, persuasive paradigm (Lilleker, 2006). It is argued that interactive tools 
will be eschewed by electoral political organisations particularly due to the risks involved (Stromer-Galley, 2000). Empirical findings reinforce this data (Ward and Gibson 1998, Newell 2001, Coleman 2001), and contrast with optimistic readings of the potential offered for politics by using an alternative, online, model of communication (Rheingold 1993, Stone 1996; Coleman \& Blumler, 2009). Web 2.0 applications such as blogs, social networking sites and filesharing sites have significantly raised hopes again. However, these are equally not without criticism. Hindman (2008) suggests that the Internet empowers only a small elite, not all citizens, and one school of thought suggests that the level of interactivity online will always be limited by political parties because inherently they seek to control their messages both offline and online (StromerGalley 2000, Tedesco 2007, Jackson and Lilleker 2009a \& b). What political parties, and individual politicians, are creating is a discrete online space, Web 1.5. While many within politics argue that this is a logical and rational strategy (Lilleker et al. 2010), perhaps Web 2.0 should be harnessed to a greater extent.

Yet greater interaction may reduce the evident and widespread disconnection between electors and the elected across the democratic nations (Stoker, 2006). Key criticisms offered of the elected by the citizen are that politics is secretive and non-transparent; politicians are untrustworthy, out of touch and self-interested; and citizens have low self-efficacy. While these factors vary across nations and their intensity can be linked to specific political or electoral contexts, research consistently suggests these are solidifying as representations of democracy as offered by the represented (Stoker, 2006; Coleman \& Blumler, 2009). It has been suggested that marketing concepts and tools can reverse these negative perceptual trends; though evidence may suggest the reverse is the case (Lilleker, 2005; Savigny, 2008). However, through an analytical assessment of the use of interactivity from a marketing perspective, we suggest interactivity can contribute to brand building and positive voter attributions of brand characters to candidates and parties seeking election.

\section{Methodology}

The research data used to underpin our analysis of the role the Internet plays in party and candidate branding strategies is developed from a number of projects undertaken over the past three years. These have been specifically focusing on mapping the way that the Internet is employed within election campaigns as well as during the permanent campaign, and to assess the extent to which Web 2.0 going mainstream has had an impact upon the nature of political communication. At the heart of this research, given its centrality to the architecture of participation to both the philosophy and design of Web 2.0 features and platforms, is interactivity as a human process. We propose this could have a revolutionary impact upon the communicational connections between parties, candidates and representatives and those whose votes, support, longer-term loyalty, as well as perhaps recognition of legitimacy to represent, that they seek.

The creation of schematics that categorises features embedded within websites in terms of their user function has become the standard key tool for testing for interactivity, though not the only method (de Landtsheer et al., 1999). This schematic has been employed in studies of candidates' websites in Germany (Gibson et al., 2003, Schweitzer, 2005), Australia (Gibson and Ward 2002), Italy (Newell et al.,2000), party websites in New Zealand (Conway and Donard, 2004) and the 
UK (Gibson and Ward 2003) as well as comparative studies (Gibson, Margolis, Resnick and Ward 2003).

Combining the Gibson and Ward schematic with the revised model based on MacMillan's four part interactivity model, as proposed by Ferber et al. (2007) we not only count the features but also assign them to specific categories: the direction of communication, one, two or three way and the extent of receiver control. This methodology operationalises the Ferber $e t$ al. model and has been used to assess interactivity within a number of contexts (Jackson and Lilleker 2009b; Lilleker and Malagon 2010; Jackson \& Lilleker, 2011). Tools and features which allow any degree of interactivity are classified according to the direction and quality of participation. The level of user control was quantified (from 0 to 10), the direction of communication classified (oneway, two-way or three-way). While such measurement tools are criticised for high levels of subjectivity when assigning the value of an element in the interactivity scale. To raise replicability and trustworthiness the original McMillan categories were operationalised, defining each point on the scale, and linking potential and actual user behaviour to numerical values (these are presented in table 1 below).

Table 1: Scale for measuring levels of receiver control

\begin{tabular}{|c|c|c|}
\hline Category & Scale & Definition \\
\hline & 1 & One-way hyperlink with unclear destination \\
\hline & 2 & One-way hyperlink with defined destination \\
\hline $\begin{array}{l}\text { Low Receiver } \\
\text { Control }\end{array}$ & 3 & $\begin{array}{l}\text { Hyperlinks created with user input, language is dynamic } \\
\text { using second person }\end{array}$ \\
\hline & 5 & $\begin{array}{l}\text { User has control over read and link options, video play } \\
\text { is optional, content can be downloaded } \\
\text { Users have control over interfacing with content } \\
\text { (above) and can send information }\end{array}$ \\
\hline & 6 & $\begin{array}{l}\text { Users can send and receive information. i.e. debate } \\
\text { forums }\end{array}$ \\
\hline High Receiver & 7 & $\begin{array}{l}\text { Users have multiple options to send and receive } \\
\text { information, their input has transformational power - } \\
\text { can be seen. i.e. text only chat. } \\
\text { Users can upload content, questions, including videos, } \\
\text { and can receive answers from receivers }\end{array}$ \\
\hline Control & 10 & $\begin{array}{l}\text { User can choose time, type and amount of information } \\
\text { sent and received, the information sent is transformed } \\
\text { by the receiver and the transformation is transparent. } \\
\text { Communication is asymmetrical } \\
\text { Sender and receiver have equal levels of control, } \\
\text { communication is conversational }\end{array}$ \\
\hline
\end{tabular}

In addition, to ensure that interpretations and explanations were intelligible (Bondarouk and Ruel 2004) medium and situational variables were taken into account (Herring 2004), these included the context of any single part of the site. These measures were included to improve the trustworthiness of the study (Lincoln and Guba 1985; Bondarouk and Ruel 2004; Herring 2004).

The first projects employing this methodology focused upon the presidential campaigns within France in 2007 and the US in 2008. Features were identified across all the websites of the candidates within the final stage of the contest, the 2nd Primary in France and the final party nominees in the US, a sample of web pages was also used to evaluate the discourse and tone of voice employed within communication - written or aural - on the website. The second project, conducted in 2008, focused on the online presences of UK Members of Parliament outside of the traditional website: weblogs, Twitter accounts, social networking profiles or filesharing site profiles. Again analysis focused on the extent to which these offered features which potentiated dialogue between the MP and the visitors to these sites. The third set of data, similar to the study 
of presidential campaign websites, focused on UK party websites during the permanent campaign in summer 2008 and then during the campaign for the European Parliamentary election of June 2009. During both projects the entire sites for the major parties were analysed, and an assessment was made regarding the extent to which interactivity was encouraged. Taken together, this data provides a rich picture of how interactivity is used across different campaigns, periods and contexts and what function it plays within political communication.

While the data was gathered in order to map the interactivity offered by parties, candidates and elected representatives, in the course of preparing this paper we revisited this data, and employed some of the concepts core to the discipline and study of branding introduced above to consider what strategic functions we could detect from the communication approach adopted by each of those being analysed. This process involved revisiting both the data and the screenshots taken of the websites, as well as observations and interpretations made in the course of writing up the research. Based on re-assessments from this fresh perspective we created a series of brand narratives regarding single interesting cases as well as, in the case of UK MPs and parties, overviews of the levels of interactivity offered. These brand narratives are designed to capture the perceptions offered by online presences.

\section{Brand Narratives}

The narratives presented in this section place the websites and online activities of candidates, representatives and parties as all being key sources of information about the brand. They are placed online strategically to have an impression upon the current and future brand relevant cognitions of site visitors. Collectively, and where there is collaboration with site visitors in shaping the overall shape of the site, they are a reflection of the diegesis presented. The different facets of the websites present this diegesis (Loponen \& Montola, 2004); a narrative of the world at the heart of the brand, its character and style and how it may perform as the provider of the ultimate service - governance. The narratives are presented mainly as text, but there are visual descriptions to demonstrate the amount of interactivity that is present across the main sites.

\section{The head of a movement - The Royal campaign in France}

The result of the first stage of the 2002 French presidential election sent a shockwave through the nation's electorate. The run-off between incumbent Jacques Chirac and neo-fascist challenger Jean Le Pen saw voters exceed any predictions when turning out to ensure Le Pen's defeat. The reason for Le Pen's unprecedented success was not that he won over anywhere near the 30-40\% usually required to reach the second stage (Fauvelle-Aymar et al., 2000), the right backed Chirac while the left fragmented across a range of candidates making Le Pen with $16.8 \%$ the second most popular candidate (Bell and Criddle 2002). The challenge for candidates during the 2007 campaign was to try to unite the left wing behind them to catapult them over the line (Le Monde, 23 April 2007); Royal's use of the Internet was a key tool in achieving this though it was unable to win her the presidency against Sarkozy who branded himself as a more traditional French leader and did not embrace any of the ideas of Web 2.0. Uther (2007) predicted that the Internet, particularly weblogs, would help candidates gain an advantage with an ever growing web-savvy electorate and Ségolène Royal fulfilled many of these predictions and put interaction via new media into the media spotlight.

While her website was constrained by the context and events of the campaign, Royal had a clear 
strategy. This involved providing a hub for progressive political ideas. Royal's website was built around a dynamic platform that changed its content by showcasing user generated content, posts and alternative voices. The voices showcased including all those captured within the 600 page Cahiers d'esperances (Notebooks of hope) that report the results of participative live and online forums that where held to develop the candidate's manifesto. While consistent with notions of the market-oriented party (Lees-Marshment, 2003), such features may not actually inform a programme but can be used to promote the brand. Arguably the main purpose for placing this document on the website was strategic. It could not have been for users to read, users rarely read politicians' manifestos (Castells 2007) and large amounts of text reduce a website's usability and readability (Nielsen 2004; George 2005). The 'Notebooks' are in reality a metaphor of the participative democracy proposal that is behind the inclusive discourse in Ségolène Royal campaign; a proposal consistent with her socialist and communitarian ideology which was used to good effect to convince the left to support her over her opponents (Péne 2007). The same can be said of the Republique des blogs (Republic of blogs), the myriad of voices found in the home page (17 distinct voices from a range of different representative individuals), and the amount of user generated content posted on parts of her website. The abundance of statements as questions, using an interrogative grammatical tone of voice (Fairclough 1995), reinforce the image of being inclusive and accessible. In addition to the site's graphic design, Royal created a multi-coloured, polyphonic platform that was much closer to the ideal of the public sphere than the targeted messages of the campaign oriented Sarkozy website (Lilleker \& Malagon, 2010).

This may give the impression that Royal's site offered a high degree of interactivity as a conversational process, however hype exceeded the reality. Royal may well have provided links to a range of voices from across what she referred to as the Segosphere, her supporter's network, and represented a range of voices and views within the 'Notebooks'; however there was little real time co-creation of content and no space for having conversations apart from one small, highlymoderated forum area. The Royal website gives a sense of a collectivist message, so reinforcing the campaign message of 'France for president': an inclusive, collectively decided and executed style of campaigning and governing. This core principle of her campaign continues through the debate section and the 'Presidential Pact', a collection of a hundred proposals developed out of participative debates. However, the interactivity presented is closer to the definition of para-social interactivity, reflections of conversations having taken place elsewhere, than that of interactivity as defined by Kiousus (2002). The only area where there was some element of co-creation was the debate forum where the sender could control the text posted and the post affected the presentation of the webpage, the debate index and the home page, which showed extracts from the debate section (even if there was a time delay). The direction of communication was qualified as three-way, for users could post comments answering questions posted by the organisation, the candidate or other users, thus continuing a conversation started by the latter. However, discourse analysis revealed that the discussions were fragmented and disjointed interventions. Overall, as Figure 1 shows, the Royal site predominantly aimed to persuade through the provision of information, there were a few elements that permitted feedback, but only eight opportunities allowed for any form of three-way, participatory conversations to take place.

\section{Figure 1: numbers for each box - Royal}

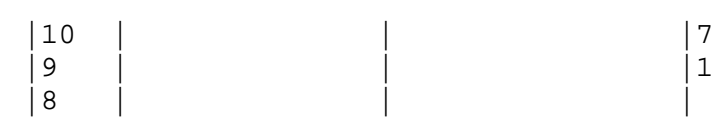




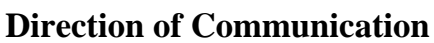

Royal presented her brand as similar to being a diviner of the general will: a channel for receiving the ideas, opinions and feedback of her supporter's network. This allowed her to position herself as the head of the left wing movement, to be their candidate and make claims that her inclusive style of candidature would translate into a more communitarian and inclusive style of presidency. The presentation of Royal within her website was highly consistent with a strategy of presenting the candidate as accessible and inclusive, and perhaps was pivotal to winning her the support of a broad left-wing coalition.

\section{The social brand - Obama as people's President}

In his autobiography, Barack Obama presented himself in three ways, using stages of his life as metaphors for his style of presidency. His youth characterised him as from the worlds of both black and white America, understanding both the hope and the despair within both communities. His life in Chicago as a community organiser places him as an in-touch people's champion, understanding the hardships of everyday life among the less affluent. His visit to his family in Kenya positions him as a man with a global perspective, understanding the issues of the third world and the role of America as a global power. In many ways this is a representation of all the facets of the Obama brand, ones used to engineer his transition from interesting outsider in the Democrat race for the nomination to clear favourite to win the White House. His online activities present a similar brand character through his political policies and personal statements; but, building upon the lessons learned on the streets of Chicago, Obama became a community organiser on a national scale and the Internet was the hub of this organisation.

The language across the site was very similar to that used by Royal, the use of 'we' rather than 'I' reinforced the communitarian ethos of his brand and his representations of the public mood 'We believe', 'This nation is...' again represent para-social interactivity; as if Obama was summing up a national conversation. Thus, in this respect, his website contained some very traditional elements. Three features earmark Obama as innovative, original and evidencing a Web 2.0 approach to political communication and campaigning. Firstly, his news was presented in a weblog format with each item allowing comments. This meant that there were 11,452 opportunities for any visitor to comment on some aspect of the campaign and comment they did; taking a sample across the dates and subject the average amount of comments per post was 184, though some posts gained close to 1,000. While common sense dictates that some moderation will have taken place, the ability to comment presents the brand as approachable, accessible and willing to listen to a range of different voices. Equally, as a feature of a website, the level of interactivity is a metaphor of the grassroots popularity of Obama as a candidate. The fact that the weblog was a hive of activity, rather than a cobweb is an outward expression of the momentum behind his campaign. Creating the weblog initially may have been a risk, but by the time the campaign gained widespread media and public attention it was a clear asset to the campaign. 
The second innovative feature was www.mybarackobama.com (MyBO) the campaign specific social network created to harness the power of the network. The opening page of the site directed visitors to $\log$ in, on doing so members of the site could then interact with other supporters and become more active participants within the campaign. This tool, which allowed registered users to join state, city or even neighbourhood communities, then went about mobilising these users to donate cash, volunteer for the campaign and made all of these tasks as easy as possible. In terms of impression management it made the campaign a communal effort across his network of supporters; while in reality the campaign was centrally orchestrated, still the activists felt they had joint ownership of the campaign so became stakeholders in the brand itself. This was the tool that allowed Obama to not only raise huge sums of money through donations and get a highly active taskforce on the streets, but also to position himself as the leader of a public movement, a president of the people in a far more profound way than Royal could claim; though it has been suggested that Obama learned everything from Royal (Montero, 2009) this is clearly not the case. Obama translated his knowledge of community organisation to the world of Web 2.0, and harnessed the power of the online supporter to the maximum benefit.

The third aspect of Obama's campaign, and one that has now become a feature of political communication, is the reaching out to other online communities and gaining a wider presence than one website can provide. Obama targeted a wide range of online communities amassing over 10 million supporters worldwide. This included twelve individual groups within MySpace, where he had a total of 1,801,305 friends on his own profile but alongside these were Students for Obama with 8,906 members, the 10,464 strong Women for Obama and Latinos for Obama with 3,557 members. His profiles on Black Planet gained 481,427 friends, there were 51,127 on MiGente the network for English speaking Latin Americans as well as 1,994 on GLEE (Gays, Lesbians and everyone else). This level of overt support, the act of befriending, coupled with the level of sharing of videos across social networks, asking friends and supporters to post badges and donate their status updates to the call of 'Vote Obama' all are demonstrations of Obama making the network work in his favour. Obama also utilised YouTube to share a range of advertisements and more private videos, each of which could be shared across all the online networks, embedded on supporters weblogs and websites and, of course, commented on. Again, this reinforces the perception of his campaign as being co-created and the concomitant images of him as being omnipresent and accessible.

Looking at the overall numbers, the majority of elements across his website and online presences allowed public conversations to take place. Team Obama would also participate to an extent, sometimes following up on comments within the comment stream or on future posts. If we are to create a blanket average for interactivity, $83 \%$ of Obama's online presence was co-created compared to less than $1 \%$ of Royal's; apart from the small forum, hyperlinks to supporters' blogs and the single, though large 'Notebooks', the website was monologic. In many ways the 2008 US presidential campaign set a new standard for political communication and this has slowly emerged as a model others attempt to follow; particularly across the pond in the UK.

\section{Figure 2: numbers for each box - Obama}

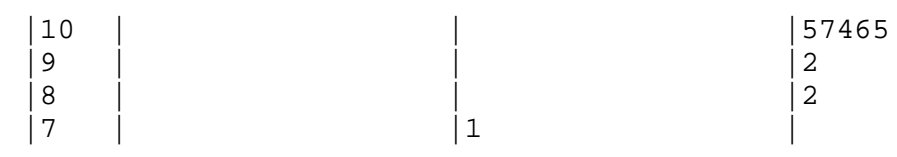

$$
57465
$$




\section{Direction of Communication}

\section{The good representative - UK MPs in conversations}

While UK political parties may have presences across social networks and have encouraged some input from visitors to their sites, these tend to be locked into private discussions from which documents are later created. Labour's Big Conversation and the Conservative's Stand Up, Speak Out initiatives being good examples; the latter being used to shape key policy areas the party would develop into a manifesto. However, they tend to be locked into what Jackson \& Lilleker (2009a) describe as Web 1.5 where an architecture of participation may be in place, but usage is not fully encouraged and it is unclear of the outcomes of participation. UK MPs, in contrast, are more able to utilise Web 2.0 tools and have conversations with their constituents, individuals interested in particular policy stances or a wider online audience who just want to interact with a member of parliament. We suggest, due to the close link between elected representatives and specific voters in geographic constituencies, that there is a huge potential for harnessing Web 2.0 platforms to interact with potential voters and so consider how MP's use such tools to brand themselves as 'good representatives'.

In mid 2008, a period with no elections and so firmly within a permanent campaigning period, we identified 37 examples of MPs using and promoting their social network presence, though this represented only 26 MPs (4\% of MPs) as nine had a presence on more than one SNS. In terms of using Web 2.0 tools and features, as with political parties (Lilleker \& Jackson, 2009a), a cursory glance suggests that an architecture of participation has been created. However, there is an imbalance in preferences for certain features. MPs are more likely to provide visitors with opportunities to interact with the site but not with the host: visitors can search over half the presences; follow a range of enmeshed links, usually to main party sites; view photographs; receive RSS feeds; follow links; and share information within their own networks (such as Facebook friends). While this appears to suggest an unwillingness to interact with visitors, there are a number of ways visitors can contact the host privately as most provide contact details or can be contacted via the site messaging service. However, the unique feature of Web 2.0 platforms is that public interaction is unavoidable. Two-thirds of weblogs allow comments, meaning any visitor can react to the hosts' post or make any comment they choose; SNS equally allow comments and postings by visitors or those who are added as friends by the MP, thus offering opportunities for public dialogue maybe unavoidable.

These profiles enhance MP's ability to communicate within their network. For some, like Liberal Democrat MP Steve Webb, communication is with a range of constituents who have "seen them in the supermarket" or who were present at "a visit to the school" and wished to interact further; for the majority however the comments are clearly from colleagues and party workers expressing support. But there is an emergent Web 2.0 compatible mode of political communication that some MPs are adopting. For example, on their weblogs, Tom Harris (Labour) often directly adds 
a comment responding to participants; and John Redwood (Conservative) will frequently respond by using the term 'Reply' at the bottom of the visitors comment and will respond to specific questions in this way. On SNS MPs such as Julia Goldsworthy and Jo Swinson (Lib Dem), or Andy Reed and Kerry McCarthy (Lab) provide a flavour of their non-political interests by identifying favourite books, music and films. Andy Reed gains comments on a wide range of issues, from education to his local rugby club. Indeed, much of the more proactive usage gains some form of positive response from their online contacts; however proactive usage seems to be a minority activity.

Overall we find that SNS, often due to the unavoidability of features that allow interactions, offer more two-way and three-way communication. With a higher receiver control over communication some visitors become participants in discussions. Weblogs are more likely to be used as informational tools, so remaining top-down communication channels consistent with political communication, but for some MPs there is a value seen in talking to their readers.

\section{Figure 3: Percentages within each category - UK MPs}

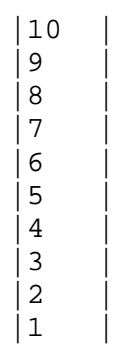

$$
\mid
$$

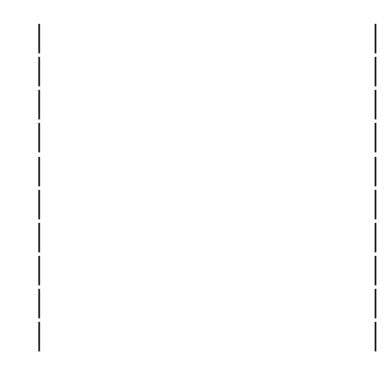

Direction of Communication

What is clear, however, that many of these profiles represent impression management exercises (Jackson \& Lilleker 2009 a \& b; Williamson 2009). Small features such as listing the employer as "the people/voters of [the constituency]", and the use of Facebook applications such as growing gifts that allow users who are friends to interact in a non-spoken way all present an image of the MP as a good representative as well as a human being. Furthermore, while a minority, some do engage in public interactive dialogue consistent with definitions offered by Rafaeli and Ferber et al: a hot topic during the period of this research was the vote on abortion law that MPs from all parties were quizzed about by a range of SNS users. This makes politics relevant to the communities to whom they speak and can engage audiences; equally it presents an image of the MP as willing to listen. For those MPs with a willingness to engage there seems to be an emergent brand of the in-touch and accessible representative, something which has increased as an activity since 2008 .

\section{The co-produced campaign? - UK parties in 2008 and 2009}

UK parties have been very tentative in the adoption of web tools, consistent with many parties across Europe they have tended to lag far behind the corporate sphere. That said, there have been some innovations though these have been described as limited within a Web 1.5 model (Jackson \& Lilleker, 2009a). While Labour's Big Conversation was criticised for being more about 
impression management than consulting the public (Lees-Marshment \& Lilleker, 2005), it did harness the Internet and started the conversation online while having supplementary offline meetings. British parties also seemed to pick up quickly on the use of social networking sites, and WebCameron the Conservative leader's personal video diary, initially had a high degree of interactivity. The fact that this was reduced as the comments feature took off demonstrates that the risks identified by Stromer-Galley (2000) remain key factors determining party adoption of Web 2.0.

However, across two periods of time, the permanent campaign period of the summer of 2008 and the European Election campaign of May 2009, we see some movement both towards more interactivity and also in the opposite direction. Taking the mean scores for each dimension and placing all parties studied in both projects within a grid (Figure 4), we may gain some indication of the level of interactivity in the run-up to the 2010 contest. The sites of the top three parties Labour (Lab), Conservatives (Con) and the Liberal Democrats (LD) show an interesting pattern. The Conservative Party remain within a controlled, two-way communication mode and this changes little across the 12 month period. The Liberal Democrats were predominantly using oneway communication in 2008, but this went clearly into a two-way mode for the European Parliament campaign while Labour became clearly more interactive with an overall average of 2.6 for direction. Given that large sections of websites, as shown earlier, are purely informational, this suggests a significant shift in communicational style. The smaller parties, Scottish (SN) and Welsh (PC) nationalists, Greens (G), UK Independence Party (U) make a range of small shifts away from a purely one-way mode of communication, UKIP being the most dramatic; the British National Party also increased their interactivity though they scored highly at both points. One party, however, reduced the overall level of interactivity; achieved by creating a basic website. The English Democrats eschewed a main web presence in 2008, instead they used the social networking site Facebook to give them free profiles for both the party and the main activists. While this remains, the website was introduced to provide basic information, so lowering their average overall due to its low sophistication.

Figure 4: Scatterplot showing mean interactivity for UK parties in 2008 \& 2009 


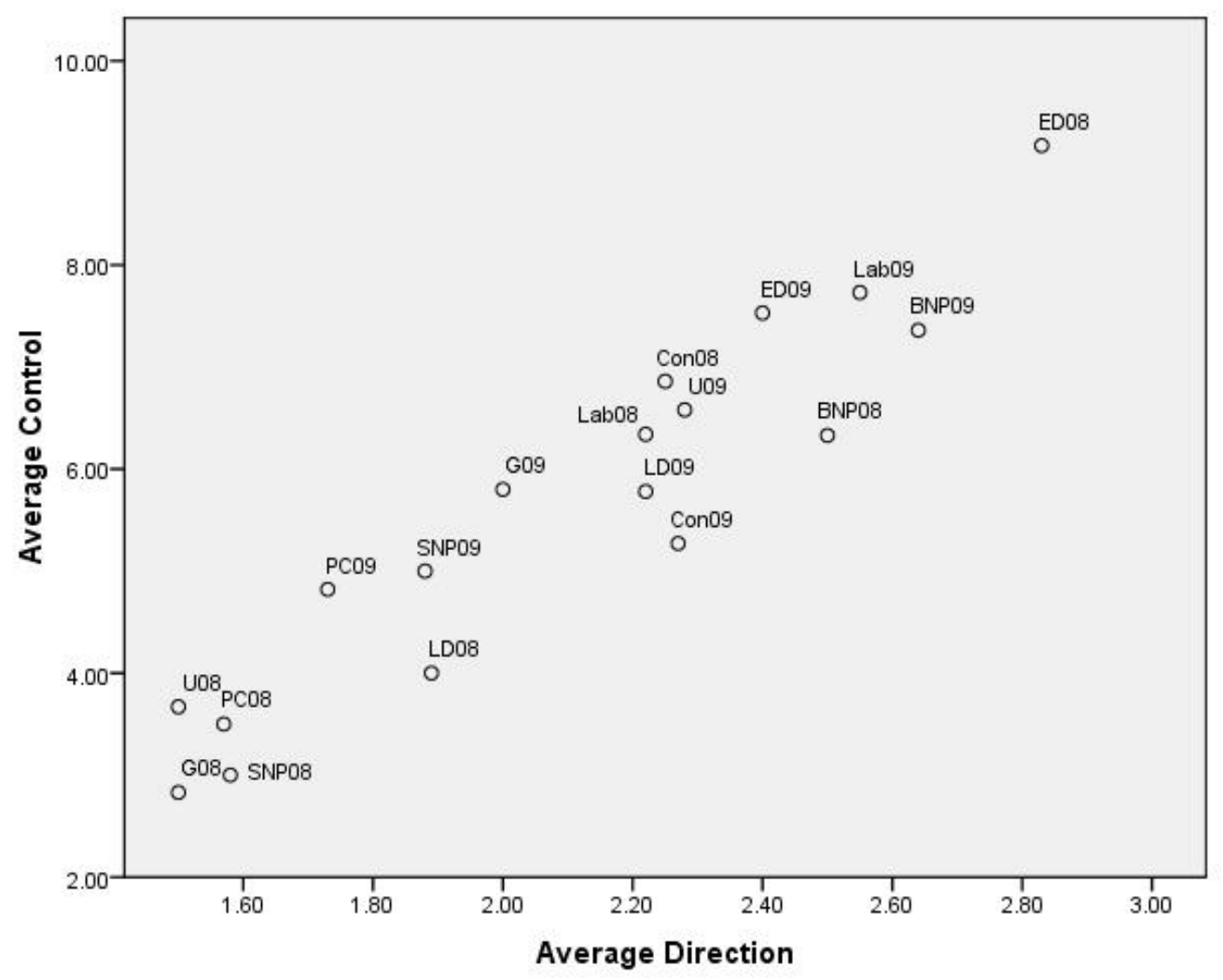

These patterns are likely to remain moving forward to the 2010 General Election. Parties with a high degree of interactivity may well retain that style in order to present themselves to visitors as open and accessible. Some parties are likely to increase significantly, the Conservatives, in particular, given the creation of www.myconservatives.co.uk, which is a mirror of www.MyBO.com, in their ongoing branding process that positions them as significantly different to that of Cameron's predecessors. It is likely that 2010 will be the UK election where the Internet comes of age as a campaigning tool. It is also highly likely, however, that public participation will be highly controlled but there will be an architecture of participation in place. Parties will use interactive tools to appear as attractive and engaging as possible to draw in visitors, then allow a range of behaviours within the site that offer a degree of interaction. This is likely to be controlled and able to be used for promotional purposes; for example Labour's campaigning site 'thechangewesee' allows supporters to upload texts and video to highlight positive change brought about by Labour. It is unclear how many of those submitted are shown, but it is clearly symmetrical. This is a feature that suggests the election will have key elements that are co-produced, and perhaps this will be the biggest feature of the forthcoming contest.

\section{Conclusion: Interactivity, Branding and Electioneering}

As with any piece of communication, a website and other various online presences provide information about the brand. While studies have shown the power of various individual features which can be used to form an impression about an organisation or candidate (De Landtsheer et al 1999; Mughan, 2000), Web 2.0 adds a new layer of features which can shape perceptions of organisations. Parties and candidates on the whole build an architecture of participation, but tend not to join this and so do not encourage its use. Obama is an outlier in this respect but he is not 
completely alone; some candidates in the UK evidence similar patterns of interactive communication. Such instances remain a minority but if such innovations can be linked to electoral benefits it may be that we see a greater amount of interactivity featuring within political communication; something that some campaign consultants argue is essential for parties (Singh, 2010) and individual representatives (Knight, 2010).

Regardless of party or candidate behaviour, election campaigns of the future are likely to be coproduced affairs. Philip de Vellis and Amber Lee Ettinger became famous for a short time during the US presidential election campaign. De Vellis was responsible for a highly negative portrayal of Hillary Clinton which became one of the most watched Clinton-related YouTube videos. Ettinger, performing as Obama Girl, made a similar impact; both her and de Vellis receiving a significant amount of media coverage. In the UK activists acting independently of the parties are waging a battle for hearts and minds via social networking sites, predominantly Facebook and Twitter. Searching for any of the main party names on Facebook is as likely to reap an independent site opposing that party as their own fan page; doing the same on YouTube and a similar effect is found. Thus while the party can attempt to manage their brand online, a whole range of easily accessible communication contests their branding and may have a greater impact.

In terms of the brand getting their message through the clutter of political messages, it may all come down to the question of credibility. Perhaps the parties will be able to have the greater share of voice. Perhaps, however, independent voices, or voices that appear to be independent, will be seen as more reflective of the public mood. This means that any electoral communication environment has an added degree of complexity and brands must be both aware of this, embrace the parts that offer potential to strengthen the brand image, but not try to control the myriad voices that may want to contribute to this ecosystem of ideas and images. While parties and candidates seem increasingly likely to use a range of new tools, platforms and media in order to present themselves to the electorate, political brands equally face significant threats from new and social media platforms that allow anyone to participate and contribute to the political communication environment. Thus future elections will be highly complex, with a range of actors playing an influential role, and the brands need to be at the cutting edge of communication in order to shape public perceptions: one way of doing this may well having public conversations with site visitors and allow a more collaborative mode of election communication.

As presidential elections tend to be one off and comparisons can only be conducted over long periods, it is interesting to use comparative data collected on the UK to indicate future trends. In the UK there is some impact on the overall political system caused by the interactivity encouraged by Web 2.0 applications. But, as suggested by Jackson and Lilleker (2009a), the major political parties appear to be creating their own Web 1.5 space, so that they maintain control over their messages. This would imply the status quo, but the smaller parties, especially those on the right, appear to be increasingly following a strategy of encouraging interactivity through Web 2.0 applications. By engaging visitors in conversation such interactivity appears to be a means by which such parties deliberately seek to draw in potential voters. Moreover, in the period 2008-2009 the rate of adoption of this strategy appeared to be increasing. There may, therefore, be two different party level approaches to Web 2.0 in the UK. Interactivity can potentially influence the visibility of a party's profile. The major parties, such as the Conservatives, Labour and Liberal Democrat can be viewed as having strong brands, in that their 
access to the media, large number of elected representatives and long histories give them a public familiarity. Clearly, the access to the mass media supports a strong brand familiarity of the big three. Traditionally, smaller parties, both those with parliamentary access and those without, can be classified as weaker brands; in that there is far less public recognition of them. However, Web 2.0 applications allow weaker brands to develop a relatively stronger online brand presence. Whilst the numbers who may become more aware is small, in proportional terms to their offline recognition, it is likely that smaller parties can develop some brand recognition online.

The importance of Web 2.0 enhanced interactivity is potentially much more significant on the UK body politic than just encouraging the development of the brand of smaller parties. More fundamentally it could be influencing the relationship between individual MPs and their parties, encouraging a more individual centred brand to be promoted at the expense of the corporate party brand. Whilst we must expect, as is the case, individual politicians as with Royal and Obama in candidate-centred political systems to use the Internet to amplify their brand, this trend is also apparent in the party-centred UK. The evidence suggests that individual MPs are much more likely to use the interactivity capabilities of Web 2.0 to help defend and build their own brand, than parties. This suggests that Web 2.0 can help MPs build up their own brand, rather than just being part of their party brand.

\section{Figure 5: Influences on voters' perception of online political brands}

\section{[pic]}

We suggest (see figure 5) that traditionally the electorate's perspective of a party brand is influenced by three factors. The first is Personal Contacts and Experience which includes voters' past experiences of the party, and what their network of friends and family say about each party. The second is the media which influences, especially during election campaigns, what voters might think of a party. The last component is the brand the party deliberately projects. This comprises branding activities which shape what image the party is trying to present. This includes at the heart of the brand image the ethos and values of the party, then the leader, followed by party policy, then leading party figures, then promotional activities, then locallyelected representatives, with the final component being party activists and members. MPs and candidates then are merely a single, and not that important, component of the party brand. However, figure 5 includes a fourth, specifically online factor which influences voters' perceptions of political brands. We suggest that as some MPs encourage interactivity through Web 2.0 applications they can develop their own brand at the potential expense of their party. So rather than merely amplifying the party brand, they can create there own, so that voters may vote for them as a personal brand. In cyberspace elected representatives and party candidates can, if they wish, develop their own brand separate to their party's. This implies that Web 2.0 interactivity can encourage a break-down of the rigid party system, and a move towards a more individualistic system. Web 2.0 creates space for a hybrid political brand including elements of both strong party and strong candidate systems. Interactivity can challenge traditional hierarchies within party based parliamentary systems such as the UK.

\section{References}

Aaker, J. (1997). Dimensions of brand personality. Journal of Marketing Research. 34 (August), 
pp. $347-357$

Anderson, P. (2007) What is Web 2.0? Ideas, technologies and implications for education, JISC Technology and Standards Watch Report, February.

Anstead, N. (2008) The Internet and Campaign Finance in the U.S. and the UK: an institutional comparison, Journal of Information Technology \& Politics, 5 (3): 285-302.

Bell, D. S., and Criddle, B. (2002) Presidentialism and the French Elections 2002. Parliamentary Affairs, 55(4), pp. 643-663.

Benhold, K. (2007) French Election strategies confound experts from America. International Herald Tribune. Saturday-Sunday, April 14-15, 2007, p. 3

Bondarouk, T., \& Ruël, H.J.M. (2004). Discourse analysis: making complex methodology simple. In: T. Leino, T. Saarinen, and S. Klein (Eds.), Proceedings of the 12th European Conference on Information Systems (ECIS). June 14-16.2004 Turku Finland.

Bucy, E. P. (2004). Interactivity in society: Locating an elusive concept. The Information Society, Vol. 20, pp. 373-383.

Castells, M. (2007) Communication, Power and Counter-power in the Network Society. International Journal of Communication, Vol. 1, pp. 238-266.

Caulfield, R. (2008) 'The Influence of "Infoenterpropagainment": Exploring the power of political satire as a distinct form of political humour', in J. C. Baumgartner and J. S. Morris (Eds) Laughing Matters, New York: Routledge, pp. 3-20.

Chadwick, A (2009) Web 2.0: New Challenges for the Study of E-Democracy in an Era of Informational Exuberance, I/S: Journal of Law and Policy for the Information Society, 5 (1): 941.

Coleman, S. (2001) 'The Online Campaign', in Norris, P. (ed.) Britain Votes, 2001, Oxford: Oxford University Press.

Conway, M. and Donard, D. G. (2004) An Evaluation of New Zealand Political Party Websites, Information Research, 9 (4): Online. Availble: http://informationr.net/ir/9-4/paper196.html (accessed 2 September 2007).

Corner, J., and Pels, D. (2001) Media and the Restyling of Politics, London: Sage.

Coleman, S., and Blumler, J. (2009) The Internet and Democratic Citizenship: Theory, Practice and Policy, Conway, M. and Donard, D. G. (2004) An Evaluation of New Zealand Political Party Websites, Information Research, 9 (4): Online. Availble: http://informationr.net/ir/94/paper196.html (accessed 2 September 2007).

Cambridge: Cambridge University Press.

de Landtsheer, C., Krasnoboka, N. and Neuner, C. (1999) Participation Friendliness of Political Websites in Eastern and Western Europe, Paper presented at the expert meeting on Political Communication and Technological Innovation, University of Perugia, December 2-4.

Deephouse, D. (2000) Media Reputation as a Strategic Resource: An Integration of Mass Communication and Resource-Based Theories, Journal of Management, 26(6), pp. 1091-1112.

Duncan, T. Moriarty, S. (1998)"A Communication-Based Marketing Model for Managing Relationships", The Journal of Marketing, 62 (2), pp. 1-13. 
Fairclough, N. (1995) Media Discourse. London: Routledge.

Fauvelle-Aymar, C., Lafay, D., and Servais, M. (2000) 'The impact of turnout on electoral choices: an econometric analysis of the French case', Electoral Studies, 19 (2-3), pp. 393-412. Ferber, P., Foltz, F. Pugliese, R. (2007) Cyberdemocracy and Online Politics: A New Model of Interactivity, Bulletin of Science, Technology \& Society, 27 (5): 391-400.

Fill, C. (2005) Marketing Communications: interactivity, communities and content, $4^{\text {th }}$ Ed, Harlow: Pearson Education.

George, C. (2005) Usability testing and design of a library website: an interactive Approach in Website Usability: Research and Case Studies. Bradford, UK: Emerald Group Publishing Limited, pp. 167-180.

Gibson, R. and Ward, S. (2002) Virtual Campaigning: Australian Parties and the Impact of the Internet, Australian Journal of Political Science, 37 (1): 99-130.

Gibson, R. and Ward, S. (2003) Online and On message? Candidates' websites in the 2001 General Election, British Journal of Politics and International Relations, 5 (2): 188-205.

Gibson, R., Margolis, M. Resnick, D. and Ward, S. (2003) Election Campaigning on the WWW in the US and the UK: a comparative analysis, Party Politics, 9 (1): 47-76.

Gibson, R., Römmele, A. and Ward, S. (2003) German parties and Internet campaigning in the 2002 Federal Election, German Politics, 12 (1): 79-104.

Grunig, J. and Hunt, T., (1984) Managing Public Relations, New York: Holt, Rinehart and Winston.

Herring, S. C. (2004). Computer-mediated discourse analysis: An approach to researching online behavior. In: S. A. Barab, R. Kling, and J. H. Gray (Eds.), Designing for Virtual Communities in the Service of Learning New York: Cambridge University Press, pp. 338-376.

Hindman, M. (2008) 'What Is the Online Public Sphere Good For?', In J. Turow and L. Tsui (Eds) The Hyperlinked Society: Questioning Connections in the Digital Age, Michigan: Digital Culture Books, pp. 268-288.

Hooghiemstra, R., 2000. Corporate Communication and Impression Management: New Perspectives Why Companies Engage in Corporate Social Reporting. Journal of Business Ethics 27 (1-2), pp. 55-68

Jackson, D. (2009) Framing Democratic Politics: An Investigation into the presence and effects of 'Strategy' news frames in the UK, Unpublished $\mathrm{PhD}$ Thesis, Bournemouth University

Jackson, N. and Lilleker, D. G. (2009a) Building an Architecture of Participation?: political parties and Web 2.0 in Britain, Journal of Information Technology and Politics, 6 (3/4): 232-250.

Jackson, N. and Lilleker, D.G. (2009b) MPs and E-representation: Me, MySpace and I, British Politics, 4 (2): 236-264.

Jackson, N. and Lilleker, D.G. (2010) Tweeting, constituency service and impression management: UK MPs use of Twitter Journal of Legislative Studies, forthcoming.

Jackson, N. and Lilleker, D.G. (2011) Political Campaigning, Elections and the Internet: Comparing the UK, UK, France and Germany, London: Routledge, forthcoming.

Keller, K.L., 1993. Conceptualizing, measuring, and managing customer-based brand equity. 
Journal of Marketing 57 (January), pp. 1-22.

Kiousis, S. (2002) Interactivity: a concept explication, New Media \& Society, 4 (3): 355-383.

Knight, J. (2010) 'Time for election 2.0?', Behind the Spin, Available online at: http://www.behindthespin.com/features/time-for-election-2-0

Lees-Marshment, J. (2001) Political Marketing and British political parties, Manchester: Manchester University Press

Lees-Marshment, J., and Lilleker, D. (2005) Political Marketing: a comparative perspective, Manchester: Manchester University Press.

Levine, D., Locke, C., Searls, D., and Weinberger, D. (1999) The Cluetrain Manifesto: The end of business as usual, London: Perseus Books.

Lilleker, D., 2005. The impact of political marketing on internal party democracy. Parliamentary Affairs, 58 (3), pp. 570-584

Lilleker, D. (2006) Key Concepts in Political Communication, London: Sage.

Lilleker, D. and Malagon, C. (2010) Making Elections Interactive: online discourse during the 2006 French presidential election, European Journal of Communication, forthcoming.

Lilleker, D., Pack, M., and Jackson, N. (2010) Political Parties and Web 2.0: The Liberal Democrat Perspective. Politics, 30 (2), pp. 105-112.

Lincoln, YS. \& Guba, EG. (1985). Naturalistic Inquiry. Newbury Park, CA: Sage

Lloyd, J. (2005) Square Peg, Round Hole? Can Marketing-Based Concepts Have a useful Role in the Political Arena?, Journal of Non-Profit and Public Sector Marketing pp. 27-46.

Loponen, M., and Montola, M. (2004) A Semiotic View on Diegesis Construction. In Montola, M. and Stenros J. (eds.) Beyond Role and Play: Tools, Toys and Theory for Harnessing the Imagination, pp. 39-51

Lusoli, W., Ward, S. J., \& Gibson, R. K. (2002). Political organisations and online mobilisation: different media - same outcomes? New Review of Information Networking, 8, 89-108.

McDonald, M., de Chernatony, L., and Harris. F. (2001) Corporate marketing and service brands - Moving beyond the fast-moving consumer goods model, European Journal of Marketing, 35 (3/4), pp. 335-352.

McMillan S. J., (2002a) A Four-Part Model of Cyber-interactivity: some places are more interactive than others, New Media \& Society, 14 (2): 271-291.

Montero, M. D. (2009) 'Political e-mobilisation and participation in the election campaigns of Segolene Royal (2007) and Barack Obama (2008)', Quaderns del CAC, 33, pp. 27-34.

Mughan, A., (2000) Media and the presidentialisation of parliamentary elections, Basingstoke: Palgrave.

Nielsen, J. (2004) Designing Web Usability: The Practice of Simplicity. Indianapolis: New Riders Publishing.

Newell. J., (2001) New Parties, New Media: Italian Political Parties and the Web, Harvard International Journal of Press Politics, 6 (4) pp60-87. 
Newell, J., Gibson, R. Ward, S. (2000) New parties, new media: Italian party politics and the Internet, South European Society and Politics, 5 (1): 123-42.

Newman, B. I. (1999) The Mass Marketing of Politics: Democracy in an Age of Manufactured Images, London: Sage.

O'Reilly, T (2005) 'What is Web 2.0', online at

http://www.oreillynet.com/pub/a/oreilly/tim/news/2005/09/30/what-is-web-20.html accessed on $12 / 9 / 07$

Pène, S. (2007) Bloguer la politique, Communication et langage. Paris: Armand Colin. No. 151. p. 39-89

Rafaeli, S. (1988) Interactivity: from new media to communication, In R. P. Hawkins, J. M. Wiemann, S. Pingree, (eds) Sage Annual Review of Communication Research: Advancing Communication Science Vol. 16, Sage: Beverly Hills, CA: 110-134.

Rheingold, H., (1993) The Virtual Community: homesteading on the electronic frontier, Reading, MA: Addison-Wesley.

Savigny, H. (2008) The Problem of Political Marketing London: Continuum.

Schweitzer, E. J. (2005) Election Campaigning Online: German Party Websites in the 2002 National Elections, European Journal of Communication, 20 (3): 327-351.

Scott, C.P. (2006) Politics and the internet: Democracy goes digital. The Guardian Available from: http://www.guardian.co.uk/ commentisfree/2006/nov/15/comment.digitalmedia

Singh, J. (2010) 'Online campaigning lessons from the US', Behind the Spin, available online at: http://www.behindthespin.com/features/online-electioneering-lessons-from-us

Stoker, G. (2006) Why Politics Matters, Basingstoke: Palgrave.

Stone, B., (1996) Politics 96 Internet World, November 1996, pp 40-50.

Street, J. (1997) Politics and Popular Culture Cambridge: Polity.

Stromer-Galley, J., (2000) Online Interaction and why candidates avoid it Journal of Communication online at http:facilty.washington.edu/pnhoward/politicsonline/Online\%Interaction.html accessed on 10/08/04.

Stromer-Galley, J. (2004). Interactivity-as-Product and Interactivity-as-Process, The Information Society, 20 (5): 391-394.

Sundar, S.S., Kalyanaraman, S., and Brown, J. (2003) Explicating Web Site Interactivity: Impression Formation Effects in Political Campaign Sites

Communication Research, 30: 30 - 59

Tedesco, J. (2007) Examining Internet Interactivity Effects on Young Adult Political Information Efficacy, American Behavioral Scientist, 50 (9): 1183-1194.

Turner, G. (2008) Ordinary People and the Media: The Demotic Turn, London: Sage.

Uther. (2007) Ségolène Royal s'invite dans Second Life. Jeuxonline [online] France: jeuxonline Available from: http://www.jeuxonline.info/actualite/ 13341/segolene-royal-invite-second-life. 
Van Dijk, J. (2005) The Network Society: Social Aspects of New Media, London: Sage.

Ward, S. and Gibson, R., (1998) The First Internet Revolution? United Kingdom political parties and campaigning in cyberspac' In Crewe, I. Gosschalk, B. Bartle, J., Political Communication: why Labour won the election of 1997? London: Frank Cass.

Williamson, A. (2009) MPs Online: connecting with constituents, London: Microsoft/Hansard Society

\section{Level of Receiver Control}

Level of Receiver Control

SNS

$44 \%$

Blog

$36 \%$

Level of Receiver Control

SNS

$38 \%$

Blog

$22 \%$

SNS

$27 \%$

Blog

$40 \%$

\section{THE ELECTORATE}

Personal contact

with the party, experiential judgements, peer group influence

Party Communication

Ethos \& Values

Key Figures

Policy Announcements

Promotional Activities

Local Representatives

Activists \& Members

Media Coverage

of party,

candidates,

key figures

and policy 
Politician's Communication

Promotional activities

Interaction with electorate

Mobilisation of activists 